\title{
The Other Side of Human Resources Accounting in the Islamic Hospital of PKU Muhammadiyah North Maluku
}

\author{
Irman Mamulati ${ }^{1}$, Djamila Abbas ${ }^{2}$ \\ \{ irmanmamulaty@gmail.com $^{1}$ \} \\ Department of Accounting, Universitas Muhammadiyah Maluku Utara ${ }^{1,2}$
}

\begin{abstract}
Human resources are debated in accounting, whether it is recognized as an asset or an expense, both of which have their own perspective. His study aims to explore the other side of human resource accounting at PKU Muhammadiyah Islamic Hospital in North Maluku. The data analysis method used in this research is interpretive phenomenology. The results show that the other side of human resource accounting is defined as a muver of da'wah, health servant, sources of revenue, and financial expenses.
\end{abstract}

Keywords: Human Resources Accounting, Asset, Interpretive Phenomenology

\section{Introduction}

Human resources (HR) are intangible assets, where they are able to realize organizational goals, both for profit and for non-profit. However, it is still being debated by both academics and practitioners since 1960 until now [20]. This was revealed by Mamulati et al., [16] that the debate was caused because HR was recognized as a expanse, while HR provided benefits where he worked. The benefit in question is that HR is able to realize the vision and mission of the organization, namely profit and non-profit.

Of course, the debate is based on that concept Financial Accounting Standards Board (FASB) was initiated that assets are resources controlled by the company as a result of past transactions and provide benefits in the future [16]. If the FASB concept is translated to recognize $\mathrm{HR}$ as an intellectual asset, it is certainly very appropriate, including: (1) when someone is accepted at a company, of course the company budget for recruitment and training costs when accepted, (2) the company controls employees regarding rights and obligations, (3) able to realize the ideals of the company, both profit and non-profit [9].

In realizing the ideals of the company, both profit and non-profit, the two things cannot be separated. According to Mamulati at al., [16] humans cannot be said to be human beings if they are assessed as separately measured variables, because humans themselves are the company's assets that have the largest contribution to the company. This was confirmed by Rodhe, et al [21] that:

In the business enterprise, a well-organized and loyal personal may be a more importent "asset" than a stock of merchandise, at present there seems to be no way of measuring such factors in terms of the dollar.

Based on the concept of HR which was initiated by Rodhe, et al. [21], HR is very very important where he works both in profit and non-profit organizations. Because HR is the most 
loyal asset, when compared to the stock of goods and is able to contribute more than material resources. Even human resources as an asset at the same time influence investors' decisions for a company, both in character [19].

Research on human resource accounting was carried out by Mamulati et al., [16] with the title Phenomenology of human resources as an intellectual asset in Mah Muhammadiyah Business Charity. Where the results of research conducted indicate that human resources as intellectual assets are interpreted as disseminators of knowledge, means of preaching, sources of revenue and also costs. Meanwhile, Kadir et al., [12] with the theme of recognizing human resource assets in achieving profit in terms of religious feminine characteristics. The results of the study found that assets from the perspective of religious femininity have a large contribution to the achievement of corporate profits. The recognition of these assets has not been realized in the financial statements but their existence is in a company and becomes a business driver.

This study aims to reveal the other side of the meaning of human resource accounting at the PKU Muhammadiyah Islamic Hospital in North Maluku. The PKU Muhammadiyah North Maluku Islamic Hospital is a Muhammadiyah charity that was established to realize the preaching of Muhammadiyah, namely eradicating superstition, bid'ah and khurafat (TBC). Thus, it will provide different meanings according to the organizational culture.

From the results of this study are expected to be able to contribute theoretically related to the meaning of human resource accounting as an intangible asset. While the practical aspect is considered to be formulated into human resource accounting.

\section{Method}

This research was conducted in a qualitative paradigm. According to Staus and Corbin [25], qualitative research is a type of research whose findings are not obtained through statistical procedures or other forms of calculation. Meanwhile, Gunawan [9] explains that qualitative research is research that does not start from a previously prepared theory but starts from the field based on the natural environment. In addition, Triyuwono [26] stated that Qualitative research is understood as research that uses qualitative data and qualitative analysis tools, namely theories that function as analytical tools.

The research method used in this research is phenomenology. Research using phenomenological methods has been widely used in accounting research [2], [11], [14]-[16], [22]. The phenomenological method is a science (logos) that studies things that are visible. Etymologically, the phenomenon comes from the Greek phainesthai meaning "who appeared". What did it reveal? it can be various: feelings, objects, events, thoughts, social institutions and so on (3). According to Denzin and Lincoln [7] that phenomenology is the science of the essences of consciousness and the ideal essence of objects as a correlation with consciousness. Phenomenology is also a philosophical approach to investigating human experience.

In phenomenological research, researchers are required to be able to describe the phenomena that occur in accordance with the reality in the field. According to Moustakas [19] phenomenology is a description of an experience. Therefore, researchers are required to consistently describe reality naturally, both by informants and their environment. Meanwhile Adian] stated that if a researcher ignores the things that appear in the subject, the research will be useless. Because the experience of the subject should always be viewed as an experience that is actively involved with the world. Therefore, researchers are required to be able to describe the phenomena that occur in accordance with the reality on the ground. 
The phenomenological method in the data collection process has its own characteristics, namely noema and noesis, where it is different from other research methods [14]. According to Moutakas [18] that Neoma is something that is accepted by the five human senses. Husserl explains that noema is faithfully and in the light of perfect self-indefence. The meaning of the word is accompanied by accurate evidence. Meanwhile, noesis is the basic ingredient of human mind and spirit. Neosis also makes us aware of meaning, when we perceive, remember, judge, feel, and think. Neosis is the ideal side of the object in our mind, not an actual object. With noesis, an object is brought into consciousness, appears in consciousness, and is rationally determined. Furthermore, humans think, feel, assess and remember using neosis. The description of noesis is a subjective description, because there is a given meaning to it.

Furthermore, according to Creswell [6] analyzing data, one of the characteristics of the phenomenological method is the epoche or bracketing developed by Husserl. Where a researcher must be able to remove the concepts that are under him or called preconcept when doing research, so as to get a pure picture (fresh perspective) of the research subject. Rapar [20] suggests that this process is one of the three phenomenological reductions in building rigorous science, so that there is no doubt (apodictic) in it. The second stage is eidetic reduction, to find eidos or the hidden nature or meaning of the observed phenomenon. At this stage the essence or meaning in question has begun to be compiled and presented in the form of specific themes. This process is carried out through careful and interactive observation, not through a linear process [5]. In other languages, through eidetic reduction, a textural description, which is the informant's experience, and a structural description that describes the context of the study can be produced. In the final stage, transcendental reduction is performed which is a key step in Husserl's transcendental phenomenology. The aim is to find the real essence or meaning, pure and whole. The process is done carefully, iteratively, and intuitively. This is the culmination of the entire process in Husserl's transcendental phenomenology, which according to Creswell is called the "essence" of the real nature or meaning of experience [6].

The main source of information in this research is informants. Researchers conducted interviews to obtain the meaning of the other side of human resource accounting. The informants used by the researchers were directly involved in the management of RSI PKU North Maluku, as well as various policies. The informants were: Mr. Ishak, Mr. Andi, dr. Pawa, dr. Arif and Mrs. Ala.

Data collection was carried out by researchers directly to informants. Moustakas [18] explains that in the process of collecting phenomenological data, the understanding, assessment, and daily knowledge of a researcher are put aside first, and the phenomenon is revised in a fresh, and as it is. So that this understanding is then followed by a recollection stage (Groenewald, 2004). The process of extracting and collecting data from informants is carried out by using indepth interview techniques and researchers as active participants, by being involved in following the people studied in their daily lives, seeing what they are doing, when, with whom, in what circumstances, and ask them about what they did. The presence of researchers as active participants is expected to provide a more complete understanding through interviews using a recording device.

The collected data were made thematic compilations, the data were sorted into sub-themes according to the research objectives. At this stage the researcher tries to make an understanding into the subject's realm of consciousness in the form of remembering, absorbing, and believing activities, where the three types of awareness activities are directed at "something" which in the methodology is called intentionality [18]. The sentence "something" in this study is the theme of the research itself, namely what and how the research subject gives meaning according to their position in RSI PKU North Maluku. 


\section{Results and Discussion}

The human resources in PKU North Maluku Hospital are divided into several parts, namely: Daily Executing Body (BPH), Health Personnel, Non-Health Personnel and Patients. North Maluku PKU RSI was donated in 2012 to Muhammadiyah North Maluku for health services by the Islamic Foundation of North Maluku City. PKU RSI North Maluku has a strategic role in carrying out da'wah in the health sector, of course it takes professionalism to manage it. Olenya, HR owned by PKU RSI North Maluku is demanded to realize good health services and according to Muhammadiyah goals

\subsection{Human Resources as a Mover of Da'wah}

The main goal of the Muhammadiyah movement in the health, education and social sectors is amar ma'ruf nahi munkar. That is, the efforts that are carried out remain consistent in doing good and preventing evil. In the health sector, namely to make people aware that being sick and healthy is the destiny of Allah SWT, so it does not deify doctors and health servant. As Pak Is disclosed that:

"Human resources at PKU Muhammadiyah North Maluku must play a role as a driver of da'wah in the health sector. Every patient who is treated is given a lecture and the Koran is read by health servant, so that the patient is aware that healing belongs to Allah SWT. As well as human resources also jointly eradicate superstition, bid'ah and khurafat in the health sector.

In addition, Pak Andi revealed that:

"Everyone must believe that healing comes from Allah SWT through medical efforts. Don't think it's a doctor who heals. We need to straighten this matter together, so that there will be no acts of doubting Allah SWT, namely Tahayul, Bid'ah and Ghurafat."

Human resources have a role as a driver of da'wah which is the main goal of Muhammadiyah's charitable efforts in upholding Islamic values, namely eradicating Tahayul, Bid'ah and Khurafat in the health sector. This goal can be said to be a non-profit achievement owned by PKU Muhammadiyah Maluku Utara. Therefore, guidance is carried out in the field of Islam and Muhammadiyah for health servant. This is intended so that health servant remain consistent in realizing organizational goals.

In addition to organizational goals, this coaching is more specific to individual awareness that a job that is done well and sincerely certainly gets thighs on Allah's side. So that collectively get benefits both individuals and institutions in carrying out the da'wah movement.

\subsection{Human Resources as a Health Servant}

Human resources in RSI PKU Muhammadiyah Maluku Utara have duties as health servants, both doctors and other health servant. The main task as a health service provider is related to patient care both inpatients and outpatients. This was addressed by Dr. Pawa, namely:

"Health servant, including doctors, nurses, analysts, nutritionists and midwives, have duties as health care servant. They provide excellent service to patients so that what they feel is satisfaction, because RSI PKU Muhammadiyah Maluku Utara is engaged in services ". Mrs. Ala added that;

"Health servant who are owned by RSI PKU Muhammadiyah are health servants so that patients served by us will always pay attention to health service standards, both administration and patient safety". 
One of the asset recognition items is that it can be controlled by the company. Health servant, including doctors, nutritionists, analysts, pharmacists and midwives, are controlled by the PKU Muhammadiyah Hospital of North Maluku in carrying out their duties as health service providers. This means that human resources are controlled according to their functions and duties, and always pay attention to health service standards, both administration and patient safety standards.

Maximum service is a priority for RSI PKU Muhammadiyah North Maluku, of course it requires human resources who have expertise in their respective fields. To realize professional services, health servant are given training through their respective professions so that patients are satisfied in terms of service.

\subsection{Human Resources as a Source of Revenue}

The implementation of health services certainly has an impact on the costs incurred by a patient, so that it has an impact on the revenue of the PKU Muhammadiyah Hospital of North Maluku. As stated by Pak Andi, namely:

"Good health services by doctors and all health servant in serving patients certainly have an impact on patient satisfaction. If the service is optimal, it will certainly provide revenue for RSI PKU Muhammadiyah Maluku Utara through fees paid by patients"

Then added Dr. Arif that

"Without all of us, namely doctors, analysts, nutrition, pharmacy and midwives, of course RSI PKU Muhammadiyah North Maluku could not provide health services. Because patients will come if the health personnel are complete and provide maximum satisfaction, so that they can give satisfaction to patients, for example, many BPJS patients prefer to go to PKU Muhammadiyah Hospital, North Maluku."

HR has a role in realizing the company's goals, which is to provide benefits in the future. If it is related to the role of human resources in contributing to revenue for the PKU Muhammadiyah Hospital of North Maluku, it can be recognized as an asset. Professional health services certainly affect patient satisfaction, as well as costs incurred as a result of these services. Future revenue is strongly influenced by the human resources at the PKU Muhammadiyah Hospital of North Maluku. Due to the ability of human resources in communication, skills and commitment that are able to make this happen. Thus it must be admitted that human resources are capable of realizing both profit and non-profit in the PKU Muhammadiyah Hospital of North Maluku.

\subsection{Human Resources as a Financial Expanses}

Running an organization certainly costs money, both for-profit and non-profit organizations. RSI PKU Muhammadiyah Maluku Utara is one of the charities in the health sector, of course it cannot be separated from the risk of costs incurred in serving the community. As stated by Pak Andi, namely:

"Human resources in carrying out their duties as health care providers, of course, have a risk of costs for doctors, analysts, pharmacy, nutrition and midwives based on basic salaries and others that arise related to patient care or other matters. In addition, they are also given training to support optimal health services. "

Pak Isaac added that 
"Human resources at RSI PKU Muhammadiyah Maluku Utara will first conduct selection and training as health servant. Because we need people who are professional and committed to the goals of Muhammadiyah ".

Financial expanses is something that cannot be separated from health service activities, both for health personnel, patient services and infrastructure for RSI PKU Muhammadiyah Maluku Utara. Therefore, human resources are given salaries, allowances and receive training facilities to support their profession. If HR is linked as an asset, the cost of recruitment and training can be used as a transaction in the past.

In addition to the financial expanses related to recruitment and training, RSI PKU Muhammadiyah Maluku Utara provides assistance to health servant who continue their professional studies. Of course, this is related to future needs, where the profession directly supports service activities.

Recognition of HR as an asset is that transactions have occurred in the past. This means that it is not only related to recruitment and training costs, but also salaries and benefits. This is related to the services provided by HR, which has economic consequences. It even requires money for Islamic and Muhammadiyah activities carried out by RSI PKU Muhammadiyah Maluku Utara.

\section{Conclusion}

HR have a role in realizing organizational goals, both for-profit and non-profit. RSI PKU Muhammadiyah Maluku Utara having human resources in the health sector has certainly achieved the goals of the organization. The purpose of establishing RSI PKU Muhammadiyah Maluku Utara upholds Islamic values and eradicates Tahayul, heresy and khurafat in the health sector that being sick and healthy is the destiny of Allah SWT and only Allah can provide health. Furthermore, HR is also a health service according to the function of RSI PKU Muhammadiyah Maluku Utara, namely serving patients. In addition, in terms of patients, it will certainly have an impact on the revenue of the PKU Muhammadiyah North Maluku Hospital through patient payments.

HR is recognized as an asset because it fulfills the criteria for asset accounting, namely that transactions occur in the past, are controllable and provide future benefits. First, HR in PKU North Maluku Hospital, before being made employees, is selected and given training to create professional services. Second, human resources in carrying out health services to patients are required to follow the applicable regulations according to the purpose of establishing the hospital. Third, human resources are able to contribute revenue through payments made by patients, both inpatient and outpatient. These three things certainly cannot be from financial expansess, where the process of moving da'wah, providing health services, and earning revenue must require economic or cost sacrifices.

\section{References}

[1] Adian, D. G. 2010. Pengantar Fenomenologi. Depok: Penerbit Koekoesan

[2] Aripratiwi, R. A., Unti, L., M, Aksin. Memaknai Sikap Integritas Akuntan Publik di KAP "Cemerlang" Surabaya (Studi Fenomenologi). Jurnal Reviu Akuntansi dan Keuangan. ISSN: 20880685, Vol. 7 No. 1, Pp 993-1002 
[3] Audifax. 2008. Research. Sebuah Pengantar untuk "Mencari Ulang". Metodologi Penelitian dalam Psikologi. Jalasutra: Yogyakarta dan Bandung

[4] Avazzadehfath, F. Decision-Making Based on Human Resource Accounting Information and Its Evaluation Method. Asian Journal of Finance \& Accounting. ISSN 1946-052X, Vol. 3, No. 1: E14

[5] Bertens, K. 1987. Fenomenologi Eksistensial. Jakarta: Gramedia

[6] Creswell, J. W. 2007. Qualitatif Inquiry and Research Design. Sage Publication, Inc

[7] Denzin, N.K. dan Y.S. Lincoln. 2009. Handbook of Qualitative Research. California-USA: Sage Publication

[8] Gunawan, I. 2013. Metode Penellitian Kualitatif Teori dan Praktik. Jakarta: PT Bumi Aksara

[9] Groenewald, T. 2004. A Phenomenological Research Design Illustrated. International Journal of Qualitative Methods, 3 (1)

[10] Harahap, S.S. 2011. Teori Akuntansi. Raja Grafindo Persada: Jakarta

[11] Irianto, G., Nurlita N., dan Putu, P. W. 2014. "Kamuflase" dalam Praktik Rotasi Auditor. Jurnal Akuntansi Multiparadigma, Volume 5, Nomor 3, Desember, Hlm. 393-408

[12] Kadir, N.R., Andi, Y. M., Wahyuddin A. 2017. Pengakuan Aset Sumber Daya Manusia Dalam Pencapaian Laba Ditinjau Dari Karakteristik Feminin Religius. Jurnal ASSETS, Volume 7, No.1, hal: 133-151

[13] Kamayanti, A. 2016. Metodologi Penelitian Kualitatif Akuntansi: Pengantar Religiositas Keilmuan. Penerbit: Yayasan Rumah Peneleh, Jakarta Selatan

[14] Latuconsina, Y. M. 2016. Mengungkap Fenomena Potongan Angsuran Murabahah di Perbankan Syariah. Jurnal Akuntansi dan Investasi, Vol. 17 No. 2, Hlm: 132-140

[15] Mamulati, I. 2015. Sisi Lain dari Aset Ekonomi. Jurnal Reviw Akuntansi dan Keuangan, 5 (2), 741 750

[16] Mamulati I. 2016. “Amal Usaha” Sebagai Aset Ekonomi Berbasis Keummatan. Jurnal Seminar Nasional dan The 3rd Call for Syariah Paper: Syariah Paper Accounting FEB UMS

[17] Mamulati, I., I. Triyuwono dan A. D. Mulawarman. 2016. Fenomenologi Sumber Daya Manusia Sebagai Aset Intelektual Dalam Amal Usaha Muhammadiyah. Jurnal Akuntansi dan Investasi, 17 (1), 93-103

[18] Moustakas, C. 1994. Phenomelogical Reseaech Methods. New Delhi: Sage Publications

[19] Ningsih, S. 2001. Perlakuan Akuntansi Sumber Daya Manusia: Assets Sekaligus Investor Bagi Perusahaan. Jurnal Akuntansi dan Investasi. Vol. 2 No. 1, hal: 13-26, ISSN: 1411-6227

[20] Rapar, J.H. 1996. Pengantar Filsafat. Kanisius: Yogyakarta

[21] Rodhe, J.G., dkk. 1976. Human Resorce Accounting: A Critical Assemnt, Issue. Industri Relationt: A Journal of Economy and Society, 15 (1), 13-25

[22] Sakri. N., Jamaluddin M., Muh, S. S. J. Mengungkap Informasi Akuntansi Usaha Kecil (Sebuah Studi Fenomenologi). Jurnal Akuntansi Peradaban: Vol. IV, No. 2, Page; 75-100

[23] Sanders, P. 1982. "Phenomenology: A New Way of Viewing Organizational Research". Academy of Management Review. 7 (3), 353-360

[24] Saerang, D., dan P. Elia. 2001. Accountability and Accounting in a Religius Organization: an Interactive Etnographic Study of the Pantecostal Chruch of Indonesia. Ph. D Dessertation, University Wallonggong

[25] Straus, A., dan J, Corbin, 2013, Dasar-dasar Penelitian Kualitatif, Yogyakarta: Pustaka Pelajar

[26] Triyuwono, I. 2013. "[Makrifat] Metode Penelitian Kualitatif [Dan Kuantitatif] Untuk Pengembangan Disiplin Akuntansi." Simposium Nasional Akuntansi ke-16, Manado 